\title{
DEFICIENT CHILDREN IN THE FAMILY
}

\author{
IX: 213-458, 2007 \\ ISSN 1212-4117 \\ László Horváth \\ University of Debrecen, Faculty of Health, Nyíregyháza, Hungary
}

\section{Summary}

The birth of a deficient child gives special tasks to the family and the environment. I examine the supporting work of health care and social providing systems. I make statements about the methods of assistance provided within the family or in residental institutions. My aim is to describe the best possible ways of connecting these services.

My method includes literary analysis and collecting data about family relationships on voluntary basis. The article contains the most up-to-date principles, procedures and the best possible ways of connecting them to each other. I give a picture of the most important declarations of the Agreement of the United Nations Organization concerning the Rights of Deficient People and of the Madrid Declaration of the European Union, as well as of the National Activity Plan accepted in Hungary. I show the process of the ability of self-sufficiency in a flow chart. This process is based on creating the supportive relationship, assessment of the individual needs, working out and applying the suitable developmental programmes needed, and the restoration of the autonomy, which should be the goal during the whole process. I deal with the principles of normalization and integration.

The World Health Organization (WHO) accepted the International Classification of Functioning, Disability and Health (ICF, in Hungarian FNO). We hope that a new conception and a new practice will begin in the international assessment of deficiency and also in the professional attitude connected to it. Its real advantage for social work is that it breaks with the impairmenttracking linear theory /e.g. International Classification of Impairments, Disabilities and Handicaps, $\mathrm{ICIDH} /$.

I describe a six-step process, which could be the up-to-date model for supporting deficient children and their families. Let me mention some of these steps: early recognition of deficiency, health care and social services provided within the family, if the deficient child is taken to a residential institution, the child should keep in touch with the family and the institution should strengthen their relationship. The research work goes on by describing how the services are connected.

Keywords: deficient children - family - self-sufficiency - principle of normalization - principle of integration

\section{Introduction to the problem}

If a deficient child is born in the family, the question arises how he/she will be brought up. This simple question, however, has its professional and moral aspects. Let me examine some of them, which are related to the health and social care. In modern societies neither the child nor the family is left alone (Katalin, László, 2006) but the forms of the assistance show a great variety.

\section{Basic question}

Where to provide the social and health care in the case of deficient children?

a. within the family

b. in residential institutions

Do the two possibilities preclude each other? If the child is put into a residential institution, what will his family connections be like in the future? If the child grows up in the family, what kind of help can the family receive? In today's 
practice we find that the two possibilities lie far from each other, in many cases they preclude each other for a long time, perhaps forever. In residential institutions some of the children are not visited by their families.

We are doing a research and trying to answer this basic question in an up-to-date way. We believe that $\mathrm{a} /$ and $\mathrm{b} /$ possibilities do not preclude each other. On the other hand, working out their relations needs a thorough professional consideration.

Another question also arises, namely, if the child is given the first type of provision, does it last forever? We think it does not, because if the child's circumstances change, we can change the forms of services. The circumstances may improve or become worse, so the provisional system cannot be rigid, it has to be flexible.

Thus, the answer can only be given, if we examine each child with the family as an individual case. First detailed assessment has to be done and the process of complex assistance can be planned according to it.

\section{Goals, Hypothesis}

For the research we set up the hypotheses as follows.

1. Staying within the family can be supported and there are several methods for this situation.

2. In residential institutions setting back into the family can be prepared in cases of certain children and conditions.

Our hypothesis is based on the belief that the best place for the child is in the family. We would like to work out the conditions needed, and the professional background of the realization. To verify the hypothesis we need to examine the most up-to-date basic principles.

\section{The Methods of Research}

I examined the hypothesis by two methods: by analysis of data from the literature on the one hand, and by accumulation of new data on the other. In the literary analysis I examined the most up-to-date principles, procedures and the contents of the statements. In the process of the data accumulation I examined the family relationships of deficient children on the basis of voluntariness of those concerned. I have finished the first part of the work, I am going to write about it in the following.

\section{Results}

New Paradigms of Taking the Social and Health Care of Deficient People

The theoretical approach is possible from several points of view. First of all, let us summarize the principles of the Madrid Declaration (Madrid Declaration, 2002) which is considered as the most important document in the European Union. The European Union declares new aspects in the case of deficiency.

There should be:

- A change in regarding deficient people as subjects of charity, deficient people should be regarded as possessors of rights.

- A change in the practice according to which decisions are made on behalf of deficient people, they should bring their own decisions and take their own responsibility in the questions they are concerned.

- A change in the point of view of focusing on individual damages. Re-examination of unimpediment, social norms, occupational policy and cultures are important, as well as creating supportive and accessible environment.

- A change in regarding people dependent and disabled. Their abilities should be emphasized and supportive measures should be brought.

- A change in the planning of economic and social processes involving few people, creating a flexible world involving many.

- A change in education, occupational policy and segregation in other areas of life, deficient people should be integrated.

- A change in ranking deficiency policy to the competency of certain ministries, deficiency policy should belong to governmental responsibilities.

With the Madrid Declaration the European Union committed itself to recommending a recipient society to everybody: , Realizing our vision of future has advantages not only for deficient people, but also for the whole society. The society that precludes its several members is an impoverished society. Measures which aim to improve conditions of deficient people result in creating a flexible world for everybody. Measures that we take today to improve deficiency policy will be sensible to everybody in tomorrow's world. We, who are participants of the 
European Deficiency Policy Congress, believe in this vision of future and call upon those concerned to regard the year 2003 as the European Year of Deficient People, as the beginning of such a process through which this vision of future will turn into reality. Fifty million European deficient people expect us to give this process a stimulus in order to realize this aim." (Madridi nyilatkozat, 2002).

In Hungary the state and occupational policy have recognized the importance of this new approach. In co-operation with the appropriate organizations of the European Union, the $\mathrm{Na}$ tional Activity Plan was born for the social affinity (Nemzeti Cselekvési Terv a társadalmi összetartozásért, 2004). Within this framework we can read about measures taken to assist deficient people's individual way of life, as well as analysis of the situation. "Their life circumstances are much more unfavourable than those of the average population in many respects. Although their level of education improved in the last decade, they are far behind the national average. Their employment figures are very bad, according to data from 2001, only $9 \%$ of them were employed, and half of them lived in households where there were no employed members at all. In order to improve the disadvantageous situation of deficient people, a law was passed about their rights and about guaranteeing their equal opportunities. In order to realize the principles set in this law, the National Deficiency Policy Programme was accepted in December 1999. The Programme determines the principles, strategic goals and tasks, which need coor- dinated state measures in order to put the law into effect, but it also builds on the local governments and their institutions, the civil organizations and the active participation of deficient people. This programme aims to determine the most important developmental directions in the following areas: physical and information accessibility, transport, health care, education, employment, sports, culture and free time, social provisions. The target of this programme is to realize equal opportunities, social integration and to guarantee the fundamental conditions for the individual way of life for deficient people through coordinated state measures, namely the interest of the deficients should be taken into account in all areas of the occupational policy (mainstreaming)".

One of the latest paradigms is the Agreement concerning the Rights of Deficient People, which was accepted by the General Assembly of the United Nations Organization (Agreement concerning the Rights of Deficient People, 2006). Its $12^{\text {th }}$ Act, which is about the equality before the law, declares that all people are legally competent and have equal capacity of action. Help should be provided to those who need it in order to exercise the disposing capacity.

The Process of the Ability of Self-sufficiency The basic approaching method of the supporting services is exposing and fortifying the ability of self-sufficiency, and the respect of autonomy. We can summarize this process in the following flow chart.

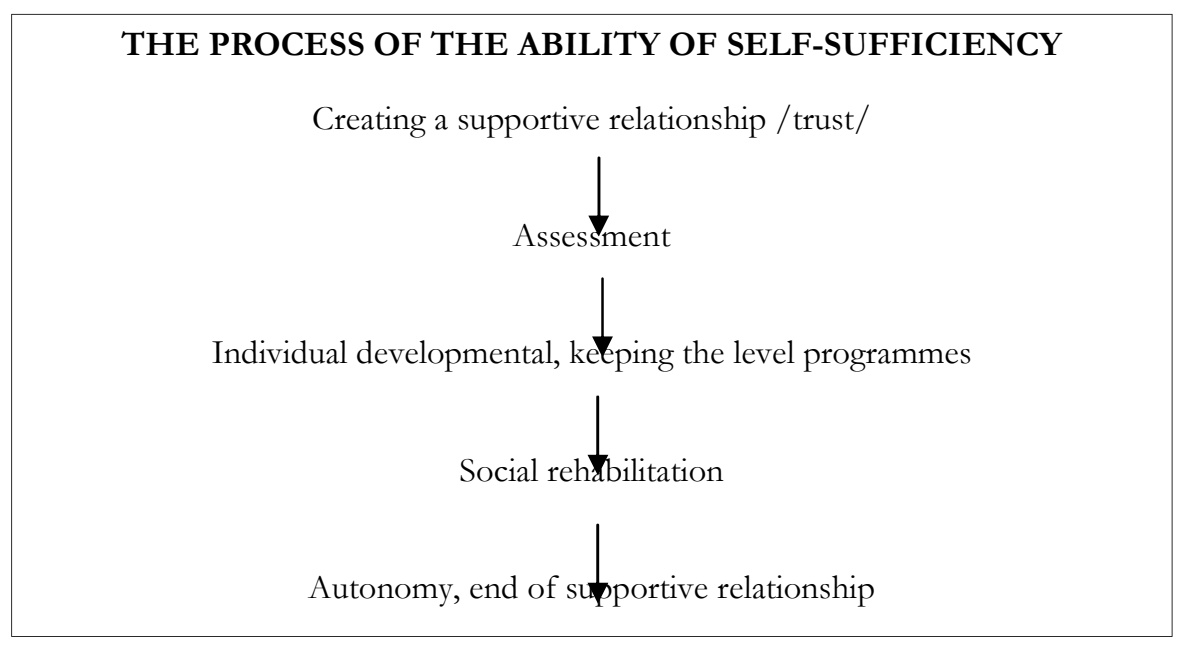


This process cannot be static, because assessment can be done again, depending on the outcome of rehabilitation. If needed, new rehabilitation services must be planned and implemented.

From the point of view of our topic we can summarize the up-to-date principles in the following:

Principle of normalization (Nirje, Perrin, 1998). Fundamentally people live in the family. Families having deficient children have to be supported.

Supporting the family where the deficient child is brought up falls in the professional field of social policy and social work.

Principle of integration. To attain social integration with the help of the family. The seclusion of deficient people and their families should be prevented, their social relationships should be preserved and strengthened by the means of positive measures.

New dimensions of International Classification of deficiency (Seidel, 2004). Stating the deficiency, classification and the determination of bases of comparison are essential for social work. It is important to state the individual and social consequences in order to decide what kind of social provisions the deficient and his/ her family should receive. That is why there is a lot of criticism about stating the deficiency in such cases when it was defined as an illness, disorder or only as a state of deficiency.

In 2001 the World Health Organization (WHO) accepted the International Classification of Functioning, Disability and Health (ICF, in Hungarian FNO). It suits the International Classification of Illnesses (BNO), on the other hand it completes it with the interactions of functioning. We can only hope that a new conception and new practice will begin in the international assessment of deficiency and also in the professional attitude connected to it. Its real advantage for social work is that it breaks with the impairment-tracking linear theory /e.g. International Classification of Impairments, Disabilities and Handicaps, ICIDH/. In contrast, it lays the emphasis on attitudes and interactions, thus opening up new possibilities for social work.

Estimation and forms of trainability. ", The question today is not whether children who demand specific education should study together with their healthy mates or in separate special institutions. The question has modified: how?"

Priority of family care and education. The task of health care and social services is the support of the family in its own environment.

Early recognition. We have achieved results in the early recognition of deficiency, but with changing efficiency. Although we are aware of the fact that the sooner we recognize the existence of deficiency, the more effectively we can adjust the social environment to it. We can start the early development only if we recognize the deficiency early.

\section{Conclusions}

\section{Tendencies of Development}

Priority of assistance given in the family is our basic principle. Assistance should be given first in the deficient's own environment.

Residential institutions are also needed, but the services provided there, should be connected to the client's own family. I am going to write about the possible processes of this connection in the following part.

\section{Services Built on One Another}

I deal with the complete process in six steps. The order of steps is important, but the duration of each step can significantly vary depending on the individuals. All these steps should be supported by a detailed and renewed assessment of necessities now and then.

1. Early recognition. The first step of the process is the early recognition of deficiency. In many cases it can be stated before the birth with the help of modern scientific instruments.

2. Assistance services should be brought to the family. Health care and social services should be improved, so that they could be brought to the client's own environment, therefore the deficient does not have to be taken out from the family.

3. In the case of serious, but temporary problems, temporary care should be provided. In the life of families such temporary problems may come up, which make the upbringing of the deficient child difficult /e.g. an illness, unemployment, a journey abroad, taking a job/. In such cases the child should not be taken out from the family permanently, only 
for the time needed.

4. Only in the case of emergency should the child be taken out from the family. Only if the child cannot be helped within his/her environment, should he/she be taken to a residential institution. In today's practice providing assistance begins at this point in many cases. We should break the tradition as much as we can.

5. Preparing the child's setting back into the family should be an important task of residential institutions. It means that the child should keep in touch with his/her family, the institution should strengthen their relationship as well. This demand requires new and up-to-date forms of work.

6. Setting back into the family. After the deficient child and his/her family had been strengthened, in some cases this lucky turn can be achieved. It is not pure chance, but it is due to conscious assistance work.

Our research work deals with the detailed assessment of this process and we work out up-to -date methods for the sake of its complete realization.

\section{REFERENCES}

KATALIN, P., LÁSZLÓ, H.: Globalization and philanthrophy in nursing. In.: Nové trendy $v$ ošetřovatelství $V$. České Budějovice, 2006.

Madridi nyilatkozat, Madrid, 2002.

Nemzeti Cselekvési Terv a társadalmi összetartozásért, Budapest, 2004.

Országos Fogyatékosügyi Program (100/1999. OGY határozat) Magyar Közlöny, 1999. 111. szám, 7357-7368 KÁLMÁN, Z., KÖNCZEI, G.: A Tajgetosztól az esélyegyenlőségig. Budapest: Osiris Kiadó, 2000. Könyvkiadó, Budapest, 2000. 2-18, 22-46, 78-91, $197-$ 200. o.

NIRJE, B., PERRIN, B.: A normalizációs elv és félreértelmezései. ÉFOÉSZ Budapest, 1998.

SEIDEL, M.: A funkcióképesség és egészség nemzetközi osztályozása (FNO). In: Szociális Munka, XVI.évf. (2004) 2.sz 70-78.o

KÖPATAKINÉ, M. M.: A befogadás megvalósulása felé. www.oki.hu

Agreement concerning the Rights of Deficient People. General Assembly of the United Nations Organization, 16th December 2006.

László Horváth dr.horvathlaszlo@freemail.hu 